\title{
Precision of Determinant in Auditor's Opinions
}

\author{
Sri Rahayu ${ }^{1}$, Abdul Rohman ${ }^{2}$ \\ \{ sri.rahayu@budiluhur.ac.id ${ }^{1}$,wayemroh@gmail.com ${ }^{2}$ \} \\ Faculty of Economy and Business Universitas Budi Luhur, Jl. Ciledug Raya, Jakarta, Indonesia ${ }^{1}$, \\ Post-Graduate Program of Economy, Universitas Diponegoro ${ }^{2}$
}

\begin{abstract}
This study aimed to analyze the influence of spiritual intelligence, professional ethics, professional skepticism, and indepence in the accuracy of givingaudit opinion. The sample of this study was the auditors who work on 14 (fourteen) Public Accounting Firm (CPA) in the area of DKI Jakarta. The data were collected by distributing 105 (a hundred and five) questionnaires, but only 94 (ninety-four) questionnaires could be processed. The data were analyzed by using multiple linear regression method with the help of Statistical Package for the Social Sciences version 19 and Microsoft Excel 2010 program. The test result showed that all independent variables such as spiritual intelligence, professional ethics, professional skepticism, and independence had a significant effect on the accuracy of audit opinion decisions. The limitations on data collection was the utilization of survey method only without conducting conversations, thus for further research, it was recommended to use an experimental method which then followed by doing interviews.
\end{abstract}

Keywords: Spiritual Intelligence, Professional Ethics, Professional Skepticism, Independence, and Accuracy of Auditor Opinion.

\section{Introduction}

The auditor's duty to examine the financial reports and provide fair opinion of a business entity's financial reports should be based on the standards established by Institute of Public Accountants Indonesia (IAPI) that consists of general standards, field work standards, and report standards to support professionalism. The final result of the audit process of company's financial reports isthe right and appropriate audit opinion based on the criteria specified in Professional Standard of Public Accountant(SPAP) that is fundamental to avoid the misleading audit result for the stakeholders (company head, shareholders, government, creditors, and employees) in the decision-making, therefore the audit should be done as appropriate as possible [1]. According to Sutton (1993), auditors who have quality in their profession are able to assure the report (information) reliability, so that the audit report can be used by the auditor to communicate with the society [2].

One of the recent major cases was occurred due to lack of auditors' independence and professional skepticism in giving opinion that revealed in the late 2011 on Olympus Corporation. This Japanese camera producer concealed losses worth US $\$ 1.5$ billion by engineeringfinancial reports and considering it as an asset. It was begun in the 1990s when theOlympus Auditor was Arthur Andersen Japan affiliate. After Andersen fell in 2002, global accounting groups KPMG acquired this company in Japan and became auditor until 2009. Then Olympus switched to Ernst \& Young at the end of the year. Financial Times in October 
2011 reported an odd opinion of KPMG related to Olympus's financial accounting. There was no dispute between KPMG and Olympus that exposed to the public, but later revealed in the November 4, 2011 on Daily Telegraph article. Similar on Ernst \& Young's opinion that did not reveal any problems asCPA KPMG and CPA Ernst \& Young considered to be failed in detecting any cheating done by Olympus Corporation. Thus during the audit of Olympus Corporation's financial report, those three CPA always present the financial statements by stating unqualified opinion which was supposed to be qualified opinion [3]. Finance Minister Sri Mulyani has set a sanction freezing business to eight public accountants and public accounting firm in 2009, one of which is Drs. Basyirudin Nur. Accountant has committed violation of Accountant Professional Standards Public (SPAP) on the implementation of public audits at PT. Samcon in 2008 that has the potential to have a significant effect on the opinion of independent auditors. The sanctions are based on Minister of Finance's regulation no.17/PMK.01/2008 concerning public accountant services [4].

Based on the above phenomenon, it can be concluded that the auditors Arthur Andersen, KPMG, and Ernest \& Young were not competent enough in auditing the financial statements of Olympus Corporation as they were fail to detect and reveal any cheating of Olympus Corporation and lack of independence and professional skepticism in giving audit opinion so that the auditor's opinion of those three CPAs regarding Olympus Corporation audit report was not presented properly.

The importance of audit opinion given by the auditor for a company induces an auditor to must obtain high spiritual intelligence. According to Hanafi (2002)"Auditors must have high spiritual intelligence so they will be really intelligent and able to synergize two other intelligence elements they have, hence any work they do will be more meaningful. The meaning appears in an organization will support every working auditor to develop themselves more. Thus, an auditor who has good spiritual intelligence and able to synergize all the components of intelligence he owns can easily consider in giving opinion precisely.

The basic thing that must be concerned by auditor is the profession ethics. The implementation of professional work cannot be separated from ethics because professional behavior is required for the profession to be trusted by society. Professional ethics are rules or standards of members'behavior of a profession. If the auditor has high ethical awareness then the auditor tends to be professional that suits the professional ethics code and auditing standards (Suharni, 2017) [6].

\subsection{Research Framework}

This study aims to analyze the spiritual intelligence, professional ethics, professional skepticism, and independence as determinant ofthe precision inaudit opinion. The theoretical framework is as follows: 


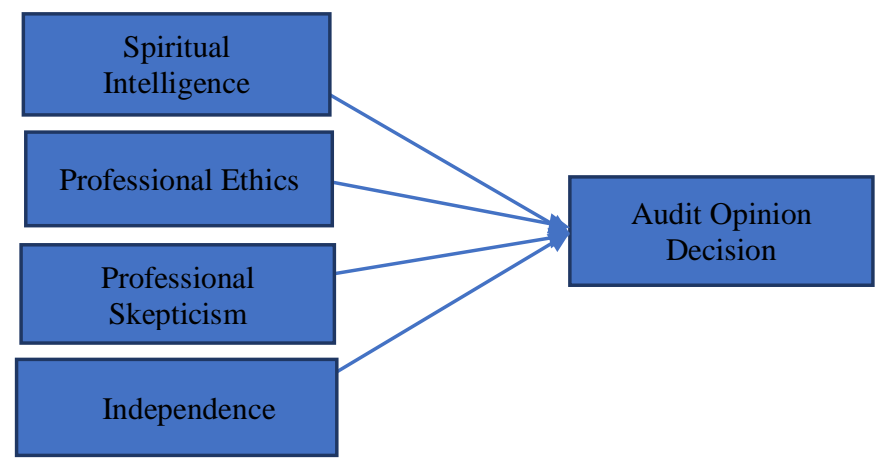

Fig. 1.Theoretical framework.

\subsection{Literature and Hypothesis Review}

Here are presented some basic theories that underlying this study along with the explanation of related variables and the relations between independent variables and dependent variable.

\subsubsection{Theory of Cognitive Dissonance}

The basic hypothesis of cognitive dissonance theory is that the dissonance will cause psychological discomfort, it will motivate a person to eliminate the dissonance and reach consonance. Dissonance is the presence of an inconsistency and a discomfort feeling that forces people to escape from the uneasiness with unmeasurable impacts. One of the requirements for professionalauditor was professional skepticism which one has to be able to collect sufficient audit evidence and not easily accept the client's explanation as a basis for providing an appropriate audit opinion in the financial reports. Cognitive dissonance occurs when the auditor has high confidence to the client that causes his professional skepticism to be at low level. Meanwhile, Standar Profesional Akuntan Publik (SPAP) require the auditor to be skeptical.

\subsubsection{Attribution Theory}

Attribution theory emphasizes the idea that a person is motivated by a pleasant outcome to feel better about himself. Attribution refers to the cause of an event or the results obtained on the basis of individual perceptions. Attribution theory is used to explain the factors that affect the success of a company, such as giving the right opinion that suits actual condition. Thus, the auditor should obtain sufficient and competent evidence with skepticism and independence, and carry out the audit procedures with consideration of risk and material [7]. Attribution theory also explains the behavior of the auditor in giving opinion that it is determined by the combination of internal forces, i.e. factors that come from within a person, such as professional skepticism and independence, and external forces which come from the outside body such as difficulties in work. 


\subsubsection{Accuracy of Auditor Opinion}

According to Özcan (2016): "The accuracy in giving audit opinion must be in accordance with the criteria set in SPAP, it is important that the audit result does not mislead the interested clients (company leaders, shareholders, creditor governments, and employees) in the decision making" [8]. Tuanakota (2013)states that Audit Opinion is part of the final stage in the audit process based on audit findings. Its dimensions include: unqualified opinions, modified unqualified opinions, qualified opinions, adverse opinions, and disclaimer of opinions [9].

\subsubsection{Spiritual Intelligence}

According to Hanafi (2002), spiritual intelligence is a moral attitude that considered as noble by the doer. A person who has high spiritual intelligence will have high ethical behavior as well. Suharni (2017) states that spiritual intelligence is the ability to give spiritual meaning to thoughts, behaviors, and activities, and able to synergize the Intellectual Quotient (IQ) and Emotional Quotient (EQ). The dimensions are: flexible, self-conscious, face and exploit suffer, overcome and transcend pain, quality of life, aversion to causing harm, have questioning mind, and independent. If the auditor has high spiritual Intelligence, scandals and manipulation act that might bedonewill not occur. The higher the spiritual intelligence of auditors, the more their ability to survive in facingthe difficulties on their duties and able to synergize all the components of intelligence they own, then the auditors can easily consider in giving their opinion appropriately [6]. The result research of Hanafi (2002) and Suharni (2017)shows that professional ethics and spiritual intelligence have significant positive effect on the auditor's opinion.

Ha1: Spiritual Intelligence has a significant positive effect on the Accuracy of Auditor's Opinion.

\subsubsection{Professional Ethics}

According to Nurdira (2015), professional ethics are the values of behavior or behavioral rules accepted and used by organizations of professional accountants such as personality, professional skills, and responsibility, code of conduct, and interpretation and refinement of the Code. Its dimensions include: Principles of integrity, principles of objectivity, principles of competence, principles, confidentiality, and principles of professional conduct. Auditors who uphold the Professional Ethics are expected to not commit fraud, thus able to provide an audit opinion objectively and appropriately. The higher the compliance level of auditor to the ethics code of his profession, the more accurate the audit opinions stated [10].

Ha2: Professional Ethics has a significant positive effect on the Accuracy of Auditor's Opinion

\subsubsection{Professional Skepticism}

According to Husnianto (2017): "Professional skepticism is a person's attitude to consider and assess an event to seek the truth of the event, try to seek the evidence, clarification, and adjustment with various perspectives and arguments" [1]. According to SPAP (2011), professional skepticism is an attitude that includes questioning minds, aware of conditions that 
may indicate possible misstatement either caused by fraud or error, and critical assessment of audit evidence. The dimensions include: ethical factors, situational and experience factors. The implementation of professional proficiency with precision and thoroughness emphasizes the responsibility of every auditor to observe the fieldwork standards and the report standards. The skeptical attitude of the auditor is expected to reflect their professional skills [11]. The result research of Nelson (2009)shows that professional accountability and skepticism have significant positive effect on the accuracy of audit opinion [12].

Ha3: Professional Skepticism has a significant positive effect on the Accuracy of Auditor's Opinion.

\subsubsection{Independence}

Tepalagul \& Lin (2015) defines Independence as impartiality attitude which is not under the influence or pressure of certain parties in making decisions or actions. Independence can also be interpreted as a state or position in which a personis not bound by any party, and does not carry the interests of certain parties. The dimensions include: Independence in fact or independence in mind and independence in appearance [13]. Lu (2006) studies point that independence has a positive effect on the accuracy of auditor's opinion. This indicates that the more independent an auditor, the more freedom the auditor get from the influence of others, so this is needed to improve the auditor's ability to objectively assess and obtain impartial judgment in determining the accuracy of the opinion given [14].

Ha4: Independence has a significant positive effect on the Accuracy of Auditor's Opinion.

\section{Method}

\subsection{Data and Samples}

The primary data in this research werecollected by spreading questioners to auditor of Public Accountant Office in DKI Jakarta which registered at Institute of Public Accountant in Indonesia 2017, with numbers of sample up to 14 Public Accounting Firm. Sampling using convenience sampling technique with sample criteria as follows:1) Public Accounting Firm (KAP) located in DKI Jakarta, 2) Public Accounting Firm that can be reached by researchers, 3) Public Accounting Firm willing to receive questionnaire.

\subsection{Data Analysis}

The analysis tools used to test and analyze the variables include the classical assumption test and multiple linear regression test using Stastical Product and Service Solution (SPSS) ver 19. Presentation of research results include descriptive data, descriptive statistics, classical assumption test results, the results of regression testing and hypothesis testing. 


\section{Results and Discussion}

\subsection{Descriptive Data}

The sample of this study was 14 Public Accounting Firm presented as follows:

Table 1. Research Sample.

\begin{tabular}{|c|c|c|}
\hline No. & Public Accountant Office & Address \\
\hline 1 & Cpa Mulyamin, Suryanto \& Lianny & Intiland Tower $7^{\text {th }}$ Fl. Jl. JenderalSudirmanKav. 32 South Jakarta 10220. \\
\hline 2 & $\begin{array}{l}\text { Cpa Noor Salim, Nursehan, } \\
\text { Sinarahardja }\end{array}$ & Jl. Anggrek 3 No. 28 Larangan Indah, South Jakarta. \\
\hline 3 & Cpa Hertanto,Grace, Karunawan & $\begin{array}{l}\text { Palma Tower, } 18^{\text {th }} \text { Fl. Lot F \& G Jl. RAKartiniII-S Kav.06 TB } \\
\text { SimatupangSouth Jakarta, Indonesia, } 12310 \text {. }\end{array}$ \\
\hline 4 & $\begin{array}{l}\text { Cpa Doli, Bambang, Sulistyanto, } \\
\text { Dadang }\end{array}$ & $\begin{array}{l}\text { Jl. MampangPrapatan VIII, No. R 25B, Tegal Parang,MampangPrapatan, } \\
\text { South Jakarta } 12790 .\end{array}$ \\
\hline 5 & Cpa Riza, Adi, Syahril \&Friends & Jl. Anggrek Garuda IX, Palmerah, West Jakarta 11480. \\
\hline 6 & Cpa Drs Moch.Zainuddi Sukmadi & Jl. Anggrek Garuda Raya Blok 1 No. 3, Slipi, West Jakarta. \\
\hline 7 & Cpa Faisal Riza, Ak, Ca, Cpa & Jl. Joglo Raya Blok H 7 No. 37 Botanic Junction, West Jakarta. \\
\hline 8 & Cpa Drs. Chaeroni \&Friends & $\begin{array}{l}\text { Jl. Anggrek Nelimurni II Blok C No. } 5 \text { Kemanggisan, Palmerah, West } \\
\text { Jakarta }\end{array}$ \\
\hline 9 & Cpa Drs R. Sunaryono \&Jailani & $\begin{array}{l}\text { Wisma IWT } 3^{\text {rd }} \text { Fl. Suite } 308 \text { Jl. ArjunaSelatan Kav } 75 \text { KebonJeruk, } \\
\text { West Jakarta. }\end{array}$ \\
\hline 10 & Cpa Jansen \& Ramdan & Gedung Jaya $4^{\text {th }}$ Fl. Jl. M.H. Thamrin No. 12 Central Jakarta 10340. \\
\hline 11 & Cpa Tjahjadi \& Tamara & Gedung Jaya $7^{\text {th }}$ Fl. Jl. M.H Thamrin No. 12 Central Jakarta 10340. \\
\hline 12 & Cpa Yuwono, H \&Friends & Jl. Arabika 8 AA2 No. 2 Pondok Kopi, East Jakarta 13460. \\
\hline 13 & Cpa Adam Nugroho & Jl. ElangThainesia C2 No. 8 Jatiwaringin, East Jakarta 13620. \\
\hline 14 & Cpa Drs A.S Akhmadwijaya & $\begin{array}{l}\text { KomplekTuguPermai Blok B1 No. } 5 \text { Jl. H. Murtado, TanjungPriuk, } \\
\text { North Jakarta }\end{array}$ \\
\hline
\end{tabular}




\subsection{Descriptive Statistics}

Table 2. Frequency Distribution of Respondents Profile by Gender.

\begin{tabular}{|ll|r|r|r|r|}
\hline & & Frequency & Fercent & Valid Percent & $\begin{array}{c}\text { Cumulative } \\
\text { Percent }\end{array}$ \\
\hline Valid L Lak-laki & 51 & 54,3 & 54,3 & 54,3 \\
& Perempuan & 43 & 45,7 & 45,7 & 100,0 \\
Total & 94 & 100,0 & 100,0 & \\
\hline
\end{tabular}

Based on the respondent's gender, it could be seen that the number of male respondents were 51 persons and the number of female respondents were 43 persons. Thus in conclusion, the average employee who working Public Accounting Firm by gender is male.

\subsection{Regression Testing Results}

The calculation results of multiple linear regression equation through SPSS ver.19.0 could be seen in table 3 as follows:

Table 3. Multiple Linear Regression Equation.

\begin{tabular}{|c|c|c|c|c|c|c|}
\hline \multirow[b]{2}{*}{ Mode } & & \multicolumn{2}{|c|}{ 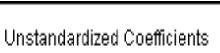 } & \multirow{2}{*}{$\begin{array}{c}\begin{array}{c}\text { Standardized } \\
\text { Coéficieients }\end{array} \\
\text { Beta }\end{array}$} & \multirow[b]{2}{*}{$\mathrm{t}$} & \multirow[b]{2}{*}{$8 \mathrm{ig}}$. \\
\hline & & $B$ & Std. Error & & & \\
\hline \multirow[t]{5}{*}{1} & (Constant) & 19,676 & 4,949 & & 3,976 & .000 \\
\hline & Kecerdasan Spiritual &, 481 &, 165 & 393 & 2,908 & ,005 \\
\hline & Etika Profesi &, 797 & 288 & .276 & 2,771 & ,007 \\
\hline & Skeptisisme Profesional & $-2,811$ &, 591 & $-1,040$ & $-4,759$ &, 000 \\
\hline & Independensi & 2,180 & .501 & 918 & 4,348 & .000 \\
\hline
\end{tabular}

Based on table 3 above, it could be obtained that the regression equation as follows:

$$
\mathrm{Y}=19,676+0,481 \mathrm{X} 1+0,797 \mathrm{X} 2-2,811 \mathrm{X} 3+2,180 \mathrm{X} 4+\varepsilon
$$

\subsection{Results of Hypothesis Testing}

Based on the output in Table 3 that spiritual intelligence variable had coefficient value of 0.481 and Sig output was known to be 0.005 , then the conclusion of Ha1 was accepted. This study isconsistent with previous research conducted by Hanafi (2010) indicating that spiritual intelligencehas a positive and significant effect on the accuracy of giving auditor opinion, where the higher the auditor's spiritual intelligence the more able it can survive in the face of difficulties during the task so that it will affect the conclusion examination as outlined in the form of auditor's opinion [5].

Professional Ethics had a coefficient value of 0.797 and the known output sig was 0.007 then the conclusion of $\mathrm{Ha} 2$ was accepted. This research is consistent with previous research conducted by Nurdira (2015)shows professional ethics have a positive and significant effect on the accuracy of giving opinion of auditor, where the higher level of auditor compliance to the code of ethics of his profession, the more accurate also given opinionby the auditor. Professional Skepticism had a coefficient value of -2.811 and a known output sig was 0.000 , 
then the conclusion of Ha3 was accepted [10]. This research is inconsistent with previous research conducted by Husnianto (2017) shows professional ethics has a positive and significant effect on the accuracy of giving opinion of auditor, where the higher level of auditor compliance to the code of ethics of his profession, the more accurate also given opinionby the auditor [1].

Independence had coefficient value of 2,180 and sig output was known to be 0,000 , hence the conclusion ofHa4 was accepted. This study is consistent with previous research conducted by Tepalagul \& Lin (2015) showing that if an auditor has a high degree of independence in the assignment of an audit, then it can affect an auditor in determining the accuracy of an opinion given. This means that spiritual intelligence, professional ethics, and independence had significant positive effect but professional skepticism had significant negative effect on the accuracy of auditor's opinion [13].

\section{Conclusion}

An auditor who has high spiritual intelligence is a person who has a strong principle and vision as well as capable to manage and survive in facing the difficulties that will affect his work performance in providing audit opinions.

Professional ethics is a medium of self-regulation that is crucial to implement the profession as expected by society. This is because every auditor is also demanded to uphold the professional ethics that has been established by Indonesian Institute of Public Accountants in order to avoid any unfair competition. By upholding the professional ethics, it is hoped that there will be no fraud among the auditors sothen capable in providing auditor's opinion that is completely based on the financial statements presented by the client.

An auditor who has professional skepticism will not take for granted the client's explanation but will ask questions to greatly obtain an answer with the most accurate audit evidence. Seeking audit evidence is necessary to clarify the opinions that will be given by the auditor to support the accuracy of audit opinion. Although the professional skepticism in deciding the audit results was in high level, the lack of capability in seeking audit evidence may affected the audit opinion that given improperly.

The higher an auditor's independence, the more freedom the auditor get from other's influence, thus will improve his ability to objectively assess and use his judgment to be impartial to anyone during the audit process.

The implication is that the auditors of the Public Accounting Firm, whether large or small, whether affiliated or not affiliated, must have high spiritual, professional intelligence and independence in order to be able to manage and survive in the face of adversity to the maximum evidence that will affect the audit / giving the auditor's opinion exactly according to the actual circumstances.

\subsection{Limitations of Research}

The limitations of this study was the usage of survey method only without followed by conducting interviews or other methods. It is suggested for further research to do analyzing with experimental method followed by interview. 


\section{References}

[1]Husnianto, "Influences Of The Auditor‘s Professional Skepticism, Competence, And Ethical Judgment," In International Conference And Call For Papers, 2017, Pp. 1391-1410.

[2]S. G. Sutton, "Toward an understanding of the factors affecting the quality of the audit process," Decis. Sci., vol. 24, no. 1, 1993.

[3]Indonesiafinancetoday.com, "No Title," 2011. .

[4]Antaranews.com, "No Title," 2017.

[5]R. Hanafi, "Spiritual Intelligence, Emotional Intelligence and Auditor' S Performance," JAAI, vol. 14 , no. 1, pp. 29-40, 2010.

[6]Suharni, "The Effect Competence , Professional Ethics Of Auditors To Work Performance And Emotional," in International Conference and Call for Papers, 2017, no. 6, pp. 669-690.

[7]A. Ardelean, "Auditors' Ethics and their Impact on Public Trust," Procedia - Soc. Behav. Sci., vol. 92, no. Lumen, pp. 55-60, 2013.

[8]A. Özcan, "Determining Factors Affecting Audit Opinion: Evidence from Turkey," Int. J. Account. Financ. Report., vol. 6, no. 2, p. 45, 2016.

[9]T. M. Tuanakota, Audit Berbasis ISA. Jakarta: Salemba Empat, 2013.

[10]G. Nurdira, "Pengaruh Etika Profesi, Komitmen Organisasi, dan Independensi Terhadap Kinerja Auditor (Survey Pada Kantor Akuntan Publik di Kota Bandung)," in prosiding penelitiansivitas akademika (sosial and humaniora), 2015.

[11]SPAP, Standar Profesional Akuntan Publik. Jakarta: Salemba Empat, 2011.

[12]M. W. Nelson, "A model and literature review of professional skepticism in auditing," Auditing, vol. 28 , no. 2, pp. 1-34, 2009.

[13]N. Tepalagul and L. Lin, "Auditor Independence and Audit Quality," J. Accounting, Audit. Financ., vol. 30, no. 1, pp. 101-121, 2015.

[14]T. Lu, "Does opinion shopping impair auditor independence and audit quality?," J. Account. Res., vol. 44 , no. 3 , pp. 561-583, 2006. 